\title{
REVIEWS
}

AleKsandra KuZAN ${ }^{A-F}$

\section{Thymosin $\beta$ as an Actin-binding Protein with a Variety of Functions}

\author{
Department of Medical Biochemistry, Wroclaw Medical University, Poland
}

A - research concept and design; $\mathbf{B}$ - collection and/or assembly of data; $\mathbf{C}$ - data analysis and interpretation;

$\mathbf{D}$ - writing the article; $\mathbf{E}$ - critical revision of the article; $\mathbf{F}$ - final approval of article

\begin{abstract}
According to current data, the thymosin $\beta$ family is composed of 20 short (40-44 amino acid) peptides, but in a healthy human body only 2 are expressed - thymosin $\beta 4$ and $\beta 10$. Their most characteristic feature is the ability to form a complex with monomeric actin, thereby preventing polymerization into a filamentous form, hence the name Actin-Binding Protein (ABP). These peptides play numerous different functions. Among others, they affect the processes of carcinogenesis, differentiation and angiogenesis, influence metalloproteinase activity and accelerate wound healing. Moreover, significant biological activity has also been displayed by T $\beta 4$ derived peptides: Ac-SDKP, the N-terminal fragment which is involved, inter alia, in stimulating angiogenesis and the inhibition of stem cell proliferation and $\mathrm{T} \beta 4$ sulfoxide, an oxidation product of one of the peptide methionine by hydrogen peroxide, which inhibit the development of inflammation. The properties of these peptides have potential applications in cardiovascular medicine, dermatology, ophthalmology and other medical areas (Adv Clin Exp Med 2016, $25,6,1331-1336)$.
\end{abstract}

Key words: thymosin $\beta$, Ac-SDKP, T $\beta 4$ sulfoxide.

\section{Thymosin as ABP with a Variety of Functions}

Thymosin is a protein, actually a group of proteins, primarily isolated from calf thymus, divided due to the isoelectric point into isoforms $\alpha(\mathrm{pI}<5), \beta(5<\mathrm{pI}<7)$ and $\gamma(\mathrm{pI}>7)[1]$. This paper will focus only on the $\beta$ isoform. The protein is already expressed in simple organisms such as echinoderms and has been evolutionarily conserved in higher organisms, but it is not detected in bacteria and microorganisms $[2,3]$.

Thymosin $\beta$ is a family of approximately 20 polypeptides, having molecular weight about $5 \mathrm{kDa}$, comprising 40-44 amino acid residues. However, it seems that mammals normally express only a thymosin $\beta 4$ (T $\beta 4$ ), and a second type, $\beta 10$ or $\beta 9$, depending on the species, e.g., in the case of humans, rats, mice, rabbits and cats $-\beta 10$, in the case of sheep, pigs, calves - $\beta 9$ [4]. In some types of tumors, thymosin $\beta 15$ is observed in a rel- atively high concentration [5]. T $\beta 4$ differs from the amino acid sequence of $\mathrm{T} \beta 10$ by $23 \%$ (10 amino acids) and of $\mathrm{T} \beta 15$ by $30 \%$ (13 amino acids) [6].

Thymosin $\beta$ is one of the actin-binding proteins (ABP). This protein forms complexes with monomeric actin at a $1: 1$ ratio, thereby inhibiting polymerization of $\mathrm{G}$ actin to filaments [7]. T $\beta 4$ prefers 50-100 fold more binding with actin associated with adenosine triphosphate (ATP) than with adenosine diphosphate (ADP) $[8,9]$. It seems that among many ABP which meet this function (e.g. $\mathrm{ADF} / \mathrm{cofilin}$ protein family), thymo$\sin \beta$ is one of the main factors responsible for the maintenance of a large reservoir of unassociated actin monomers [10]. Moreover, $\mathrm{T} \beta$ also binds to the filamentous actin form, but only if it is present in a concentration above $20 \mu \mathrm{M}$ [9]. In this situation it weakens the contact between the monomers forming the filament, promoting its greater twisting [11]. Transient overexpression of T $\beta 4$ increases the concentration of monomeric actin in relation to its filamentous form and the loss of stress fiber 
tension [12]. Long-term overexpression causes an increase in both $\mathrm{G}$ as $\mathrm{F}$ actin amount, which consequently does not change their mutual relationship. Moreover, in case of the long-term overexpression of $\mathrm{T} \beta 4$, an increase in the concentration of other cytoskeletal proteins such as myosin IIA, $a$-actinin, vinculin, and tropomyosin is also observed. At this time, the concentrations of total protein, DNA, profilin and actin depolymerizing agents are the same. It has been observed that cells overexpressing T $\beta 4$ for a long time exhibit greater mobility and undergo stronger adhesion than control cells [13].

$\mathrm{T} \beta 9, \mathrm{~T} \beta 10$ and $\mathrm{T} \beta 15$ have about two times higher affinity for $\mathrm{G}$ actin than $\mathrm{T} \beta 4$. On the basis of this fact, it is postulated that among the many mechanisms of increasing the mobility of the cells by reducing the concentration of the polymerized actin, there are at least two mechanisms related to thymosin: increasing concentrations of $\mathrm{T} \beta 4$ or replacement of T $\beta 4$ with T $\beta 10$ [11].

Thymosin $\beta 4$ is present in the greatest concentration in the cells of all the $\beta$ thymosins, that is, on average, about $0.4 \mathrm{mM}$ (from $1 \times 10^{-5}$ to $\left.5.6 \times 10^{-1} \mathrm{M}\right)$, which represents $70-80 \%$ of the total concentration of the thymosin $\beta$ [14]. This peptide consists of 43 amino acids, has a mass of $4.9 \mathrm{kDa}$ and its $\mathrm{pI}$ is 5.1 . It is mainly located in the cytoplasm and is present in many tissues and cells, particularly in macrophages, blood cells except erythrocytes and tumor cells [14]. T $\beta 4$ is also found in relatively high concentrations in the serous fluid of blisters, ulcers, wounds, blood serum and urine [15]. In adult human serum, it is present at a concentration of about $12.6 \mathrm{ng} / \mathrm{mL}$ (range 6.9-23 ng/mL) [16].

\section{Ac-SDKP}

Ac-SDKP is a tetrapeptide having the sequence $\mathrm{N}$-acetyl-aspartyl-serine-lysine-proline. It is produced by the hydrolysis of T $\beta 4$ at its N-terminus by the enzyme POP (propyl oligopeptidase) between the Pro4 and Asp5. It stops pluripotent stem cells in the G0/G1 phase, thus preventing their entry into the $S$ phase. It is hydrolyzed by ACE (angiotensin-converting enzyme) [17]. In the event of it becoming blocked (e.g. by administration of captopril), Ac-SDKP concentration in the blood increases up to 5-fold [18]. It is credited with strong characteristics for inhibiting the expression of collagen and TGF $\beta$ (transforming growth factor $\beta$ ), limiting fibroblast proliferation, infiltration of macrophages, inhibiting the development of inflammation and accelerating neovascularization $[18,19]$.

\section{T $\beta 4$ Sulfoxide}

In monocytes and neutrophils, in the presence of oxidizing agents such as $\mathrm{H}_{2} \mathrm{O}_{2}$, T $\beta 4$ sulfoxide is generated, with oxidized methionine residue at position 6 [20]. In such form, thymosin has a lower affinity for monomeric actin [21], however, it is characterized by high biological activity. It is postulated that the compound modulates the immune cells, inhibits the activity of interferon- $\gamma$ with a positive effect on wound healing, and other processes associated with inflammation [22].

\section{Functions of of Thymosin $\beta 4$}

The main function of thymosin $\beta$ is to maintain the pool of monomeric actin, which affects the dynamics of the cytoskeleton rearrangement, and therefore the mobility of cells, the capacity of differentiation, cell division, etc. Other functions are often associated with the fact that the protein is one of the ABPs, but not always. They are quite numerous and varied, and the main are included in Table 1. Some of the most important of them will be described in more detail below.

\section{Participation of T $\beta 4$ in Angiogenesis}

It has been discovered that the thymosin family, despite the large structural homology, has peptides in its group with opposite properties relating to regulating angiogenesis. It was demonstrated that $\mathrm{T} \beta 4$, $\mathrm{T} \beta 15$, thymosin $\alpha 1$ and a prothymosin accelerated angiogenesis, but $\mathrm{T} \beta 10, \mathrm{~T} \beta 9$ and parathymosin $\alpha$, which differ from T $\beta 4$ by 10 amino acids (outside actin-binding motif), significantly inhibited this process [38].

It is postulated that $T \beta 4$ is of such importance in angiogenesis that if there is no active protein as a result of gene damage or disorder in gene expression, it induces disturbances in cell migration, differentiation, causes hemorrhaging and partial embryonic lethality. Rossdeutsch et al. demonstrated this experimentally on germline null for $\mathrm{T} \beta 4$ and a second line in which T $\beta 4$ was knocked down by endothelial-specific expression of T $\beta 4$ shRNA [39]. In the work, arguments were shown that endothelial T $\beta 4$ stimulates differentiation of mesodermal cells to a mature mural by enhancing the activity of TGF $\beta$ signaling. It was also demonstrated that retardation of the TGF $\beta$ pathway correlates with the penetrance of hemorrhage in T $\beta 4$-null aortas and modification in downstream signaling. The authors concluded that this information may help analyze the reasons for congenital abnormalities of the blood vessels, which in adulthood could 
Table 1. Selected functions and mechanisms of action of thymosin $\beta$

\begin{tabular}{|c|c|c|}
\hline Functions & Mechanism of action & References \\
\hline \multirow[t]{3}{*}{$\begin{array}{l}\text { Stimulation } \\
\text { of angiogenesis }\end{array}$} & $\begin{array}{l}\rightarrow \text { stimulates the secretion of VEGF-A, which accelerates endothelial cell mitosis } \\
\text { and migration }\end{array}$ & 23 \\
\hline & $\rightarrow$ affects expression of metalloproteinases MMP-2 and MMP-9 & 24,25 \\
\hline & $\rightarrow$ recruits stem cells & 26,27 \\
\hline \multirow{4}{*}{$\begin{array}{l}\text { Inhibition of } \\
\text { atherosclerosis } \\
\text { and drifting effects } \\
\text { of ischemia }\end{array}$} & $\begin{aligned} \rightarrow & \text { inhibits TNF- } \alpha \text { (tumor necrosis factor) } \rightarrow \text { induces NFKB (nuclear factor- } \\
& \text { kappa B) activation }\end{aligned}$ & 28 \\
\hline & $\rightarrow$ activates ILK (integrin-linked kinase) & 29 \\
\hline & $\rightarrow$ decreases the infiltration of white blood cells & 22 \\
\hline & $\rightarrow$ reduces apoptosis $\rightarrow$ promotes cell survival & 28 \\
\hline $\begin{array}{l}\text { Accelerating the healing } \\
\text { of skin wounds }\end{array}$ & $\begin{array}{l}\rightarrow \text { stimulates fibrinolysis inhibitor PAI-1 (plasminogen activator inhibitor } \\
\text { type } 1 \text { ) } \rightarrow \text { accelerates the migration of endothelial cells }\end{array}$ & 30,31 \\
\hline $\begin{array}{l}\text { Accelerating the healing } \\
\text { of corneal scarring }\end{array}$ & $\begin{array}{l}\rightarrow \text { stimulates the production of laminin- } 5 \rightarrow \text { regulates migration of endothelial } \\
\text { cells of the cornea and conjunctiva }\end{array}$ & $32-34$ \\
\hline \multirow[t]{3}{*}{$\begin{array}{l}\text { Regulation of the } \\
\text { immune system }\end{array}$} & $\begin{array}{l}\rightarrow \text { inhibits the production of } N F K B \rightarrow \text { inhibits the expression of acute-phase pro- } \\
\text { teins }\end{array}$ & 34 \\
\hline & $\rightarrow$ inhibits neutrophil chemotaxis & 20 \\
\hline & $\rightarrow$ inhibits stem cells proliferation & 35 \\
\hline \multirow{2}{*}{$\begin{array}{l}\text { Participation in the } \\
\text { development of cancer }\end{array}$} & $\rightarrow$ interacts with actin $\rightarrow$ increases mobility of cells & 6,36 \\
\hline & $\begin{array}{l}\rightarrow \text { increases the level of ERK (extracellular signal-regulated kinases) phosphory- } \\
\text { lation } \rightarrow \text { induction of resistance to cytotoxic anti-cancer drugs (paclitaxel, } \\
\text { doxorubicin and etoposide) }\end{array}$ & 37 \\
\hline
\end{tabular}

manifest in a tendency to form aneurysms and lethal bleeding [39].

It was also found that T $\beta 4$ not only plays an important role in the formation of blood vessels, but also may be important in the regeneration of damaged vessels. Shelton and Bader [40] reported that T $\beta 4$ mobilizes mesothelial cells for tissue repair. An experiment demonstrating this phenomenon consisted of potentiating omental grafts with agarose beads soaked in T $\beta 4$. This peptide stimulated omental cells to migrate and differentiate into smooth muscle cells in the damaged area, wherein the mesothelial cells of the graft were integrated into the wounded vessel and reconstructed the smooth muscle layers, which influenced the time of healing of the grafted vessels in vivo, reducing it considerably [40]. This information indicates the therapeutic potential of thymosin in medicine.

\section{Role of T $\beta 4$ in the Regulation of Inflammatory Response}

It is postulated that $T \beta 4$ is capable of inhibiting the inflammatory response. There are reports that it has an impact on the multi-stage activation of $\mathrm{NFKB}$, the transcription factor which activates ma- ny pro-inflammatory genes [33]. Experiments were performed in which the inflammatory process was induced by the cytokine TNF- $\alpha$ and then the cells were treated with $\mathrm{T} \beta 4$. It turned out that a reduction occurred of nuclear NFKB amount, its activity and the degree of phosphorylation of its key subunit, $\mathrm{p} 65$. It is suggested that a block takes place in these cells of translocation of the p65 subunit to the nucleus [33]. There are also reports that $\mathrm{T} \beta 4$ sulfoxide, which is formed by monocytes in the presence of glucocorticoids, also inhibits inflammatory responses [20].

\section{$\mathrm{T} \beta 4$ in the Functioning of the Heart}

Of particular relevance to cardiovascular physiology is angiogenesis occurring during the development of the heart, when the outer layer of EPDC (epicardial derived cells) undergo transition from epithelial cells to mesenchymal and migrate into the deeper layers, the myocardium and subepicardium. After that, their differentiation into specific cell types occurs [27]. It also takes place under the influence of growth factors. Some of them, VEGF and bFGF (basic fibroblast growth factor), result 
in differentiation into endothelial cells of coronary arteries. The second group, PDGF (platelet derived growth factor) and TGF $\beta$, causes transformation to smooth muscle cells which form the muscular layer of the veins and arteries of the heart.

It has been discovered that the role of $\mathrm{T} \beta 4$ in this process is the stimulating of progenitor cells to move into deeper layers of the heart. This fact is demonstrated by experiments with mice with a deletion mutation that causes a lack of cardiac expression of thymosin. In this case, EPDC undergo transitions to mesenchymal cells but do not have the ability to migrate and are trapped in the outer layer of the heart. Cells expressing $\alpha$-SMA ( $\alpha$-smooth muscle actin) and endothelial specific receptor Tie2 have been identified on the surface of this organ, thus it can be concluded that the purpose of these cells was to transform into endothelial cells [27]. As a result, the coronary arteries are less numerous, tissue has abnormal structure and is poorly supplied with blood and nourished [27]. It was also discovered that $\mathrm{T} \beta 4$ may mobilize progenitor cells from the circulation, as well as from the epicardium [28]. The discovery of this mechanism may be important in the therapeutic strategies of cardiac diseases, in the regeneration of heart cells in patients after myocardial infarction or long-term ischemic disease. The assumption is that cell precursors may be used, avoiding the risk of transplanted stem cell rejection by the patient's immune system [27].

\section{Thymosin as a Factor which Regulates Inhibition of Scarring}

It has been reported that $\mathrm{T} \beta 4$ positively influences healing by reducing scarring, inter alia, the heart after myocardial infarction. One of the experiments conducted on mice with artificially-induced myocardial infarction consisted of injecting $\mathrm{T} \beta 4$ once directly into the heart and in the form of several injections into the peritoneal area. The results were positive, the thymosin treated animals exhibited greater survival of myocardial cells and reduced scar formation by $53 \%$ at 4 weeks. The migration of progenitor cells from the inner layers of the heart and their differentiation into new coronary vessels was also found [28].

$\mathrm{T} \beta 4$ sulfoxide has also been shown to modulate scarring. It has been proven that T $\beta 4$ sulfoxide stimulates wound healing and reduced scarring in mice after myocardial infarction [41]. It is known that it inhibits neutrophil chemotaxis and interferon- $\gamma$ antiviral activity, and causes the dissipation of monocytes, which prevents the formation of foci of chronic inflammation and allows proper wound healing without the formation of non-functional scars [41].

\section{Therapeutic Potential of T $\beta 4$}

A large number of researchers have postulated that thymosin has great therapeutic potential. To test the safety of a formulation containing $\mathrm{T} \beta 4$, a series of experiments was done. On the basis of trials with transgenic mice, it appears that an excess (50 fold) of the protein did not result in adverse side effects in survival, but only had a negative impact on the development of dentition during fetal growth [28]. The tests performed with rats and dogs, which were administered endogenous $\mathrm{T} \beta 4$, showed no significant adverse effects of the protein. In the tests already carried out with humans, the results are promising, and provide evidence of the safety and efficacy in the therapeutic effect of T $\beta 4$ use [28].

Similar hopes are associated with Ac-SDKP [19]. This peptide is so short that synthesizing it under laboratory conditions is relatively uncomplicated and not very expensive, which is an additional, unquestionable advantage. All these facts speak for the fact that Ac-SDKP is potentially a good pharmacological agent.

\section{Summary and Conclusions}

The analysis of the data makes it possible to conclude that thymosin $\beta$ has a wide variety of functions in the body. Major activities which it exhibits are: actin binding, promotion of cell migration, angiogenesis, an anti-inflammatory and anti-apoptotic action, promoting wound healing, inhibition of fibrosis, stem cell recruitment and differentiation., protection from burns, cytotoxic agents and hypoxia [7, 24, 25, 27, 28, 30, 33]. It is worth noting that disturbances in the expression of this protein may have serious clinical consequences, particularly in the context of cancer [6, $36,1,23]$. On the other hand, the experimental data supports the thesis about the potential therapeutic properties of T $\beta 4$ and derivatives of this peptide-sulfoxide and Ac-SDKP. These molecules are considered to be a potential factor applicable in the treatment of cardiovascular diseases, corneal and skin wounds and brain injuries $[19,20,22,28]$. Based on an understanding the numerous activities of T $\beta 4$, it is postulated that the peptide will be used in the treatment of, inter alia, myocardial infarction, chronic heart failure, diabetes, lupus, stroke, multiple sclerosis, pressure ulcers, burns, dry eye, viral infections and septic shock [28]. Early clinical trials show $\mathrm{T} \beta 4$ to be safe, well tolerated and effective in dermal and eye wound healing. Similarly, clinical trials on the use of this peptide as a drug for heart disease are underway and expected to obtain promising results [28]. 


\section{References}

[1] Chen C, Li M, Yang H, Chai H, Fisher W, Yao Q: Roles of thymosins in cancers and other organ systems. World J Surg 2005, 29, 264-270.

[2] Sanders MC, Goldstein AL, Wang Y: Thymosin $\beta 4$ (Fx Peptide) is a potent regulator of actin polymerization in living cells. PNAS 1992, 89, 4678-4682.

[3] Stoeva S, Hörger S, Voelter W: A novel $\beta$-thymosin from the sea urchin: extending the phylogenetic distribution of $\beta$ thymosins from mammals to echinoderms. J Pept Sci 1997, 3, 282-290.

[4] Yang SP, Lee HJ, Su Y: Molecular cloning and structural characterization of the functional human thymosin $\beta 4$ gene. Mol Cell Biochem 2005, 272, 97-105.

[5] Lere B, Massimo L, Bruce RZ: Thymosin $\beta 15$ expression in tumor cell lines with varying metastatic potential. Clin Exp Metastasis 1998, 16, 227-233.

[6] Bao LR, Loda M, Janmey PA,Stewart R, Anandapte B, Zetter BR: Thymosin $\beta 15$ : A novel regulator of tumor cell motility upregulated in metastatic prostate cancer. Nat Med 1996, 2, 1322-1328.

[7] Smart N, Rossdeutsch A, Rile PR: Thymosin $\beta 4$ and angiogenesis: modes of action and therapeutic potential. Angiogenesis 2007, 10, 229-241.

[8] Carlier MF, Jean C, Rieger KJ, Lenfant M, Pantaloni D: Modulation of the interaction between Gactin and thymosin $\beta 4$ by the ATP/ADP ratio: Possible implication in the regulation of actin dynamics. Proc Natl Acad Sci USA 1993, 90, 5034-5038.

[9] Carlier MF, Didry D, Erk I, Lepault J, Van Troys ML, Vandekerckhove J, Perelroizen I, Yin H, Doi Y, Pantaloni D: Thymosin $\beta 4$ is not a simple G-actin sequestering protein and interacts with F-actin at high concentration. J Biol Chem 1996, 271, 9231-9239.

[10] Bindschadler M, McGrath JL: Relationships between Actin Regulatory Mechanisms and Measurable State Variables. Annals of Biomedical Engineering 2007, 35, 995-1011.

[11] Sun HQ, Kwiatkowska K, Yin HL: $\beta$ thymosins are not simple actin monomer buffering proteins. Insights from overexpression studies. J Biol Chem 1996, 271, 9223-9230.

[12] Lin, SC, Morrison-Bogorad M, Yin HL: Effects of thymosin $\beta 4$ and thymosin $\beta 10$ on actin structures in living cells. Cell Motil Cytoskeleton 1994, 27, 13-25.

[13] Golla R, Philp N, Safer D, Chintapalli J, Hoffman R, Collins L, Nachmias VT: Coordinate regulation of the cytoskeleton in 3T3 cells overexpressing thymosin $\beta 4$. Cell Motil Cytoskeleton 1997, 38, 187-200.

[14] Hannappel E, Xu GJ, Morgan J, Hempstead J, Horecker BL: Thymosin $\beta 4$ : A ubiquitous peptide in rat and mouse tissues.Proc. Natl Acad Sci USA 1982, 79, 2172-2175.

[15] Huff T, Rosorius O, Otto AM, Muller CS, Ballweber E, Hannappel E, Mannherz HG: Nuclear localisation of the G-actin sequestering peptide thymosin beta 4. J Cell Sci 2004, 117, 5333-5341.

[16] Franco FJ, Diaz C, Barcia M, Arias P, Gomez-Marquez J, Soriano F, Mendez E, Freire M: Synthesis and apparent secretion of prothymosin alpha by different subpopulations of calf and rat thymocytes. Immunology 1989, 67, 263-268.

[17] Cavasin MA, Rhaleb NE, Yang XP, Carretero OA: Prolyl oligopeptidase is involved in release of the antifibrotic peptide Ac-SDKP. Hypertension 2004, 43, 1140-1145.

[18] Cingolani OH, Yang XP, Liu YH, Villanueva M, Rhaleb NE, Carretero OA: Reduction of cardiac fibrosis decreases systolic performance without affecting diastolic function in hypertensive rats. Hypertension 2004, 43, 1067-1073.

[19] Yang F, Yang XP, Liu YH, Xu J, Cingolani O, Rhaleb NE, Carretero OA: Ac-SDKP reverses inflammation and fibrosis in rats with heart failure after myocardial infarction. Hypertension 2004, 43, 229-236.

[20] Young JD, Lawrence AJ, MacLean AG, Leung BP, McInnes IB, Canas B, Pappin DJ, Stevenson RD: Thymosin $\beta 4$ sulfoxide is an anti-inflammatory agent generated by monocytes in the presence of glucocorticoids. Nat Med $1999,5,1424-1427$.

[21] Huff T, Zerzawy D, Hannappel E: Interactions of $\beta$-thymosins, thymosin $\beta 4$-sulfoxide, and N-terminally truncated thymosin $\beta 4$ with actin studied by equilibrium centrifugation, chemical cross-linking and viscometry. Eur J Biochem 1995, 230, 650-657.

[22] Evans MA, Smart N, Dubé KN, Bollini S, Clark JE, Evans HG, Taams LS, Richardson R, Lévesque M, Martin P, Mills K, Riegler J, Price AN, Lythgoe MF, Riley PR: Thymosin $\beta 4$-sulfoxide attenuates inflammatory cell infiltration and promotes cardiac wound healing. Nat Commun 2013, 4, 2081.

[23] Cha HJ, Jeong MJ, Kleinman HK: Role of thymosin beta 4 in tumor metastasis and angiogenesis. J Natl Cancer Inst 2003, 95, 1674-1680.

[24] Blain EJ, Mason DJ, Duance VC: The effect of thymosin beta 4 on articular cartilage chondrocyte matrix metalloproteinase expression. Biochem Soc Trans 2002, 30, 879-882.

[25] Philp D, Scheremeta B, Sibliss K, Zhou M, Fine EL, Nguyen M, Wahl L, Hoffman MP, Kleinman HK: Thymosin $\beta 4$ promotes matrix metalloproteinase expression during wound repair. J Cell Physiol 2006, 208, 195-200.

[26] Rossdeutsch A, Smart N, Rile PR: Thymosin $\beta 4$ and Ac-SDKP: Tools to mend a broken heart. J Mol Med 2007, 86, 29-35.

[27] Smart N, Risebro CA, Melville AAD, Moses K, Schwartz RJ, Chien KR, Riley PR: Thymosin $\beta 4$ induces adult epicardial progenitor mobilization and neovascularization. Nature 2007, 445, 177-182.

[28] Goldstein AL, Hannappel E, Sosne G, Kleinman HK: Thymosin $\beta 4$ : a multi-functional regenerative peptide. Basic properties and clinical applications. Expert Opin Biol Ther 2012, 12, 37-51. 
[29] Bock-Marquette I, Saxena A, White MD, Dimaio JM, Srivastava D: Thymosin $\beta 4$ activates integrin-linked kinase and promotes cardiac cell migration, survival and cardiac repair. Nature 2004, 432, 466-472.

[30] Malinda KM, Sidhu GS, Mani H, Banaudha K, Maheshwari RK, Goldstein AL, Kleinman HK: Thymosin $\beta 4$ accelerates wound healing. J Invest Dermatol 1999, 113, 364-368.

[31] Al-Nedawi KN, Czyz M, Bednarek R, Szemraj J, Swiatkowska M, Cierniewska-Cieslak A, Wyczolkowska J, Cierniewski CS: Thymosin $\beta 4$ induces the synthesis of plasminogen activator inhibitor 1 in cultured endothelial cells and increases its extracellular expression. Blood 2004, 103, 1319-1324.

[32] Sosne G, Hafeez S, Greenberry AL II, Kurpakus-Wheater M: Thymosin $\beta 4$ promotes human conjunctival epithelial cell migration. Curr Eye Res 2002, 24, 268-273.

[33] Sosne G, Qiu P, Christopherson PL, Wheater MK: Thymosin $\beta 4$ suppression of corneal NFkappaB: A potential anti-inflammatory pathway. Exp Eye Res 2007, 84, 663-669.

[34] Sosne G, Siddiqi A, Kurpakus-Wheater M: Thymosin $\beta 4$ inhibits corneal epithelial cell apoptosis after ethanol exposure in vitro. Invest Ophthalmol Vis Sci 2004, 45, 1095-1100.

[35] Leeanansaksiri W, DeSimone SK, Huff T, Hannappel E, Huff TF: Thymosin $\beta 4$ and its N-terminal tetrapeptide, AcSDKP, inhibit proliferation, and induce dysplastic, non-apoptotic nuclei and degranulation of mast cells. Chem Biodivers 2004, 1, 1091-1100.

[36] Goldstein AL: Thymosin $\beta 4$ : A new molecular target for antitumor strategies 67. JNCI 2003, 95, 1646-1647.

[37] Oh SY, Song JH, Gil JE, Kim JH, Yeom YI, Moon EY: ERK activation by Thymosin-beta-4 (T $\beta 4$ ) overexpression induces paclitaxel-resistance. Exp Cell Res 2006, 312, 1651-1657.

[38] Koutrafouri V, Leoniadis L, Avgoustakis K, Livianou E, Czarnecki J, Ithakissios D, Evangelatos G: Effect of thymosin peptides on the chick chorioallantoic membrane angiogenesis model. Biochim Biophys Acta 2001, 1568, 60-66.

[39] Rossdeutsch A, Smart N, Dubé KN, Turner M, Riley PR: Essential role for thymosin $\beta 4$ in regulating vascular smooth muscle cell development and vessel wall stability. Circ Res 2012, 111, 89-102.

[40] Shelton EL, Bader DM: Thymosin $\beta 4$ mobilizes mesothelial cells for blood vessel repair. Ann N Y Acad Sci 2012, 1269, 125-130.

[41] Evans MA, Smart N, Dubé KN, Bollini S, Clark JE, Evans HG, Taams LS, Richardson R, Lévesque M, Martin P, Mills K, Riegler J, Price AN, Lythgoe MF, Riley PR: Thymosin $\beta 4$-sulfoxide attenuates inflammatory cell infiltration and promotes cardiac wound healing. Nat Commun 2013, 4, 2081.

\section{Address for correspondence:}

Aleksandra Kuzan

Department of Medical Biochemistry

Medical University of Wroclaw

ul. Chałubińskiego 10

50-368 Wrocław

Poland

Tel.: +48717841387

E-mail: aleksandra.kuzan@gmail.com

Conflict of interest: None declared

Received: 8.08.2014

Revised: 26.09.2014

Accepted: 3.10.2014 